\title{
A Marriage By Any Other Name: Why Civil Unions Should Receive Federal Recognition
}

Deborah A. Widiss

Indiana University Maurer School of Law, dwidiss@indiana.edu

Andrew Koppelman

Northwestern University School of Law, akoppelman@law.northwestern.edu

Follow this and additional works at: https://www.repository.law.indiana.edu/ijlse

Part of the Constitutional Law Commons, and the Sexuality and the Law Commons

\section{Recommended Citation}

Widiss, Deborah A. and Koppelman, Andrew (2015) "A Marriage By Any Other Name: Why Civil Unions Should Receive Federal Recognition," Indiana Journal of Law and Social Equality. Vol. 3 : Iss. 1 , Article 3. Available at: https://www.repository.law.indiana.edu/ijlse/vol3/iss1/3

This Article is brought to you for free and open access by the Law School Journals at Digital Repository @ Maurer Law. It has been accepted for inclusion in Indiana Journal of Law and Social Equality by an authorized editor of Digital Repository @ Maurer Law. For more information, please contact rvaughan@indiana.edu.

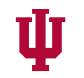

JEROME HALL LAW LIBRARY

INDIANA UNIVERSITY

Maurer School of Law
Blooming ton 
Volume 3: Issue 1

\title{
A Marriage By Any Other Name: Why Civil Unions Should Recieve Federal Recognition
}

\author{
Deborah A. Widiss* \& Andrew Koppelman**
}

\section{INTRODUCTION}

Once upon a time, not very long ago, there were more states where a same-sex couple could enter into a civil union or domestic partnership than states where they could marry. ${ }^{1}$ In the wake of United States $v$. Windsor ${ }^{2}$ the federal government has largely ended its discriminatory policy of denying recognition to

* Associate Professor, Indiana University Maurer School of Law

** John Paul Stevens Professor of Law and Professor of Political Science, Northwestern University. Both authors thank Patricia Cain, Douglas NeJaime, Julie Wilensky, and Tobias Barrington Wolff for extremely helpful comments and Pegeen Bassett for research assistance. We are also grateful to the editors of the Indiana Journal of Law and Social Equality for their extremely conscientious work.

1. In July 2011, nine states, plus the District of Columbia, permitted same-sex couples to form civil unions or domestic partnerships that provided full or virtually full state-level spousal rights, while only six states, plus the District of Columbia, permitted same-sex couples to marry; at that time, there were three additional states that had created alternative statuses that provided partial spousal rights. See Marriage Equality \& Other Relationship Recognition Laws, Hum. RTs. CAMPAIGN (July 6, 2011), http://www.hrc.org/state_maps (on file with author). Analysis of data from the 2010 census suggests that, at that time, there were approximately 220,000 same-sex couples in formal legal relationships, split almost evenly between those who were married and those who were in civil unions or domestic partnerships. See Brief for Gary J. Gates as Amicus Curiae on the Merits Supporting Respondent Windsor at 25, United States v. Windsor, 133 S. Ct. 2675 (2013) (No. 12-307).

2. 133 S. Ct. 2675 (2013). 
same-sex couples who are married. ${ }^{3}$ However, the federal government still refuses to recognize alternative legal statuses that impose precisely the same rights and responsibilities on couples as marriage and which were explicitly created to be equivalent to marriage. This misguided and discriminatory policy is based on a mindlessly literalist approach to statutory interpretation that should be repudiated.

To be sure, the harms caused by the federal government's policy have been mitigated by the rapid expansion of marriage rights at the state level. All of the states that currently permit, or previously permitted, couples to enter into such alternative statuses have also begun permitting same-sex couples to marry, and it is likely that the Supreme Court may soon hold that the remaining state bans on samesex marriage are unconstitutional. ${ }^{4}$ Nonetheless, the denial of federal recognition to alternative statuses continues to be problematic for several reasons. There are some same-sex couples who formed civil unions or domestic partnerships when marriage was not an option that now may lack the capacity to marry; for such couples, the putative availability of legal marriage is of no avail. ${ }^{5}$ Couples who entered into an alternative status and have since married may be hurt by the federal government's refusal to recognize civil unions or domestic partnerships retroactively, even in situations where it is now recognizing marriages retroactively. ${ }^{6}$ And finally, some couples may remain in, or enter into, alternative statuses precisely because they have determined that it is advantageous to be "married" for state purposes but "unmarried" for federal purposes. ${ }^{7}$ While this is permissible under the existing statutory regimes, it threatens to subvert the policy choices that are built into the interlocking federal and state systems.

The federal government's explanations for denying recognition to civil unions or domestic partnerships have been remarkably opaque, but they seem to have something to do with the fact that these unions are not called "marriages."

3. The federal government now recognizes same-sex marriages as valid for most purposes, even if the couple lives in a state that does not recognize the marriage. However, married couples living in non-recognition states are still denied key rights under the Social Security Act and certain veterans' benefits. See Deborah A. Widiss, Non-Marital Families and (or After?) Marriage Equality, 42 FLA. St. U. L. Rev. 547 (2015).

4. Alternative statuses providing full or partial spousal rights are available in ten states plus the District of Columbia. Civil Unions \& Domestic Partnership Statutes, Nat'L Conf. OF St. LegisLATURES (last updated Nov. 18, 2014), http://www.ncsl.org/research/human-services/ civil-unions-and-domestic-partnership-statutes.aspx. All of these states also now permit samesex couples to marry; the expansion of marriage rights in many of these states was required by court decisions holding that the denial of marriage rights was unconstitutional. See States, Freedom to Marry, http://www.freedomtomarry.org/states/ (March 4, 2015). A pending Supreme Court case may well result in nationwide marriage rights for same-sex couples. See DeBoer v. Snyder, 772 F.3d 388 (6th Cir. 2014), cert. granted sub nom. Bourke v. Beshear, 135 S. Ct. 1041 (2015) (No. 14-574).

5. See infra text accompanying note 59 .

6. See infra text accompanying notes 60-62.

7. See infra text accompanying notes 63-64. 
The government appears to embrace what we shall call the Name Claim: a union must be designated by the word "marriage," in the jurisdiction that recognizes it, in order to be treated as a marriage in federal law.

The Name Claim is false. Since the founding of the country, federal law has recognized countless marriages that are not called "marriages" in the original recognizing jurisdiction. These are marriages from foreign countries where the language spoken is not English. Whatever word is used, the status created is the functional equivalent of marriage in American law and so is treated as such. This claim is similarly inapposite as applied to civil unions or domestic partnerships that are likewise functional equivalents to marriage. These alternative statuses were developed as a compromise to permit same-sex couples to access the full range of administrative benefits and supports of marriage, and commit to the obligations of marriage, while denying them the name. Couples who enter into such unions thus make exactly the same legal commitments to each other that couples who marry make to each other. Indeed, in the pre-Windsor world, the federal government treated them as marriages, denying recognition even where federal statutes otherwise would have required it. ${ }^{8}$ In the post-Windsor world, they similarly should be treated as marriages. Because the Name Claim is false, and because that claim is the basis for distinguishing "domestic partnerships" and "civil unions" from marriages, alternative statuses that provide full state marital rights should be recognized as triggering "marital" benefits and obligations under federal law.

Part I of this Article describes state domestic partnerships and civil unions. Part II describes the federal refusal to recognize them after Windsor. Part III argues that just as the federal government routinely recognizes foreign marriages, even when called something other than "marriage," it should recognize state civil unions or domestic partnerships that are likewise legally indistinguishable from state-level marriages.

\section{Civil Unions and Domestic Partnerships as Marriage Equivalents}

The practice of designating legal recognition of same-sex couples by some name other than marriage was a political compromise. It arose as part of an effort to disaggregate two different issues in the same-sex marriage debate.

That debate is really two different debates. The first is a normative debate about what relationships to value or even to sanctify. The second is a debate about administration - about which relationships ought to have legal consequences.

The normative debate, which has religious dimensions for many, concerns what relationships are intrinsically valuable. The key question is one about objective moral reality: are same-sex relationships as such morally equal to heterosexual 8. This is most evident in the Social Security context. See infra text accompanying notes 26 and $36-37$. 
relationships, or do heterosexual relationships partake of a good that homosexual relationships cannot possibly share?

On this issue, Americans are divided, with different groups adhering to two very different moral visions. According to the anti-same-sex-marriage vision, sex can be morally worthy precisely and only because of its place in procreation. Even the marriages of infertile heterosexual couples take their meaning from the fact that they form a union of the procreative kind, and their bodily union therefore has procreative significance. From this perspective, the movement for same-sex marriage is a misguided attempt to deny fundamental moral distinctions. ${ }^{9}$

According to the pro-same-sex-marriage moral vision, sex is valuable either in itself or because it draws us toward friendship of a singular degree and kind. This bringing together of persons has intrinsic worth, whether or not it leads to childbearing or child-rearing. On this account, sexuality is linked to the flourishing of the next generation only to the extent that it is one of a number of factors that can bond adults together into stable familial units in which children are likely to thrive. It is not necessary or even important that the children be the biological product of the adults' sex acts. From this perspective, it is the devaluation of same-sex intimacy that is immoral, because it reflects arbitrary and irrational discrimination.

The administrative debate concerns what relationships between persons ought to be given legal recognition. Here the issue is the more mundane one of how resources should be allocated and unfair disruption of people's lives prevented. Like it or not, relationships of dependency exist in households of every kind. From those relationships, one can reasonably infer what the members of those households would want and need if some unprovided-for contingency arises, such as the illness or death of one of them.

Because the moral and the administrative questions are distinct, many U.S. states opted to grant same-sex couples the rights of married couples without the honorific of "marriage." The first state to do so was Vermont, which enacted a civil union law in 2000 in response to a court order to create a status that was functionally equivalent to marriage. ${ }^{10}$ Over the next fourteen years, thirteen additional states created civil unions or domestic partnerships that provided full state-level spousal

9. For a fuller description and critique of this view, see Andrew Koppelman, Judging the Case Against Same-Sex Marriage, 2014 U. ILL. L. Rev. 431 (2014). Government action premised on many of the assumptions underlying this view violates constitutional sex discrimination principles. See Andrew Koppelman, Why Discrimination Against Lesbians and Gay Men is Sex Discrimination, 69 N.Y.U. L. Rev. 197 (1994); Deborah A. Widiss, Elizabeth L. Rosenblatt \& Douglas NeJaime, Exposing Sex Stereotypes in Recent Same-Sex Marriage Jurisprudence, 30 HARV. J.L. \& GENDER 461 (2007).

10. An Act Relating to Civil Unions, 1999 Vt. Laws 91 (largely codified at Vt. Stat. Ann. tit. 15, §§ 1201-1207 (2002), tit. 18, §§5160-5169 (2000) (repealed 2009)). Vermont stopped permitting same-sex couples to form civil unions when it began permitting them to marry. See An Act Relating to Civil Marriage, 2009 Vt. Laws 3, § 12. 
rights. ${ }^{11}$ Some, like Vermont's, were created to satisfy guarantees of equality under state constitutions. ${ }^{12}$ In other states, such as California, the rights and obligations available under a more limited domestic partnership were gradually expanded until the status encompassed full marital rights. ${ }^{13}$ And in a few states, such as Colorado, civil unions were created as a mechanism to provide same-sex couples with the benefits and protections of marriage without running afoul of a state constitutional amendment limiting marriage itself to the union of a man and a woman. ${ }^{14}$ In many states, these alternative statuses were only available to same-sex couples; in a few states, they were available to same-sex and different-sex couples. ${ }^{15}$

Civil unions and domestic partnerships are controversial. Many conservatives think that same-sex relationships are morally wrong and should not be given any recognition at all by the state. Gay rights advocates object that withholding the name of "marriage" implies an inferior status. But their legal effect is clear. Under state law in most U.S. jurisdictions, these alternative statuses are treated as marriages.

Importantly, this is true even though the myriad provisions of state law that reference marriage were not themselves amended to add a reference to a "domestic partner" or "member of a civil union." Rather, the acts that created the statuses either globally redefined "marriage" and "spouse" to include these alternative statuses or globally granted the rights of marriage to couples in such statuses.

For example, New Jersey's Civil Union Act provides that:

Whenever in any law, rule, regulation, judicial or administrative proceeding or otherwise, reference is made to "marriage," "husband," "wife," "spouse," "family," "immediate family," "dependent," "next of kin," "widow," "widower," "widowed" or another word which

11. States or jurisdictions that created alternative statuses that, at least at some times, provided full or virtually full marital rights were: California, Colorado, Connecticut, Delaware, District of Columbia, Hawaii, Illinois, New Hampshire, New Jersey, Nevada, Oregon, Rhode Island, Vermont, and Washington. See NAT'L Conf. of St. LegisLatures, supra note 4. The rights accorded under a few of these states' regimes differed slightly from those available under marriage, but they were in almost all respects functionally equivalent to marriage. We refer to the statuses in these jurisdictions as according "full" marriage rights, as opposed to the kind of limited domestic partnerships that excluded many key marital rights, such as those in Maine and Wisconsin. See id.

12. See, e.g., An Act Concerning Marriage and Civil Unions, 2006 N.J. Laws 103, § 1; An Act Relating to Civil Unions, 1999 Vt. Laws 91, §§ 1-2 (Adj. Sess.); see also Lewis v. Harris, 908 A.2d 196, 213-14 (N.J. 2006).

13. See, e.g., Melissa Murray, Paradigms Lost: How Domestic Partnership Went from Innovation to Injury, 37 N.Y.U. Rev. L. \& Soc. Change 291 (2013) (describing the evolution of domestic partnership rights in California law).

14. See Colo. Rev. Stat. Ann. §§ 14-15-101, 102 (West 2005 \& Supp. 2014).

15. States where they are or were available to same-sex and different-sex couples include Hawaii and Illinois, as well as California where only different-sex couples over the age of sixty-two may register as domestic partners. NAT'L Conf. OF St. Legislatures, supra note 4. 
in a specific context denotes a marital or spousal relationship, the same shall include a civil union .... ${ }^{16}$

Similarly, Nevada's Domestic Partnership Act provides that:

Domestic partners have the same rights, protections, and benefits, and are subject to the same responsibilities, obligations, and duties under law, whether derived from statutes, administrative regulations, court rules, government policies, common law or any other provisions or sources of law, as are granted to and imposed upon spouses. ${ }^{17}$

And Oregon's domestic partner law, the Oregon Family Fairness Act, provides that:

Any privilege, immunity, right or benefit granted by statute, administrative or court rule, policy, common law or any other law to an individual because the individual is or was married, ... is granted on equivalent terms, substantive and procedural, to an individual because the individual is or was in a domestic partnership . . . ${ }^{18}$

In other words, these statutes make clear that these alternative statuses are legally equivalent to marriage and that parties to a civil union or a domestic partnership are legally equivalent to spouses. Couples who enter into "full" civil unions or domestic partnerships thus agree to exactly the same bundle of obligations and promises to support each other that married couples do. ${ }^{19}$

16. N.J. Stat. Ann. § 37:1-33 (West $2002 \&$ Supp. 2014) (emphasis added); see also, e.g., 750 Ill. Comp. Stat. Ann. 75/10 (West 2009 \& Supp. 2014) (“'Party to a civil union' means, and shall be included in, any definition or use of the terms 'spouse,' 'family,' 'immediate family,' 'dependent,' 'next of kin', and other terms that denote the spousal relationship, as those terms are used throughout the law.").

17. Nev. Rev. Stat. Ann. § 122A.200(1)(a) (LexisNexis 2010) (emphasis added). Colorado's Civil Union Act includes almost exactly the same language. Colo. Rev. Stat. Ann. § 14-15-107 (West 2005 \& Supp. 2014). See also Cal. Fam. Code $§ 297.5$ (West 2004); HaW. Rev. Stat. § 572B-9 (West 2008 \& Supp. 2013); 750 Ill. Comp. Stat. Ann. 75/5 (West 2009 \& Supp. 2014) (all including similar provisions globally granting members of civil unions or domestic partnerships all the rights, obligations, and duties of spouses).

18. Or. Rev. Stat. $§ 106.340$ (2013) (emphasis added). There are a few very small distinctions between rights under Oregon's domestic partner law and under its marriage law. See Geiger v. Kitzhaber, 994 F. Supp. 2d 1128, 1134-35 (D. Or. 2014) (identifying a few distinctions).

19. Indeed, as Melissa Murray has noted, when California expanded the rights and obligations of domestic partnership to full marital rights, there was a notable uptick in dissolution of the earlier, more limited domestic partnerships, presumably because couples did not want to owe each other full marital rights. See Murray, supra note 13, at 302-03. 
Broadly speaking, there are three primary reasons why a couple might enter into an alternative status. ${ }^{20}$ The first - and most obvious - is that for many samesex couples, it was a mechanism to express their love and commitment, and obtain the tangible rights and benefits of marriage, when marriage itself was precluded. In other words, for these couples, the alternative was a second-best substitute. But there are also likely some same-sex (and, in states where permitted, differentsex) couples who affirmatively chose to enter into an alternative status precisely because it was not marriage - that is, it was a way to acknowledge commitment to a partner by forming a union that was not tainted by marriage's exclusionary and patriarchal history. And finally, there are also likely some couples who may act for instrumental, rather than ideological or political, reasons. These couples may have rationally decided that it is advantageous to be treated as "married" under state law but not under federal law. For example, when Windsor was decided, there was widespread discussion of the extent to which federal tax law can impose a "marriage penalty" on couples who make roughly the same level of income; some couples might therefore have opted to remain in an alternative status rather than marry. ${ }^{21}$ Importantly, some states explicitly invited such considerations by making alternative statuses available to different-sex couples only if they were over age sixty-two; this permits older adults to formalize a new relationship without risking the discontinuation of federal Social Security benefits or other pension benefits they might be receiving as a widow, widower, or divorcee. ${ }^{22}$

\section{Federal Nonrecognition of Civil Unions}

More than one thousand federal rights or benefits are premised on marriage; these laws generally use marriage as an efficient (although imprecise) proxy for identifying couples who have made long-term commitments to each other and

20. Our thanks to Doug NeJaime for helping us articulate these distinctions.

21. See, e.g., Same-Sex Marriage After DOMA, The Kojo Nnamdi Show (July 8, 2013), http://thekojonnamdishow.org/shows/2013-07-08/same-sex-marriage-after-doma/transcript (advising same-sex couples in DC who would pay a marriage "penalty" to form a DC domestic partnership instead).

22. See, e.g., WASH. Rev. Code $§ 26.60 .010$ (West 2014) (legislative finding stating "the public interest would be served by extending rights and benefits to couples in which either or both of the partners are at least sixty-two years of age .... [who] are entitled to marry under the state's marriage statutes, [but where] some social security and pension laws nevertheless make it impractical for these couples to marry"); see generally Carla Hartley, How Changes in Domestic Partnership Laws Affect Our Senior Citizens, Avvo (Aug. 14, 2010), http://www. avvo.com/legal-guides/ugc/how-changes-in-domestic-partnership-laws-affect-our-senior-citizens (discussing how forming an alternative status may be advantageous to senior citizens); Lornet Turnbull, Heterosexual Seniors Lost in the Furor over Domestic Partnership, SeatTle TiMES (Sept. 6, 2009, 5:54 PM), http://seattletimes.com/html/localnews/2009814434_r71seniors06m.html\#_ga=1.161430269.179428502.1423012443. 
who have likely integrated their finances. ${ }^{23}$ Prior to the enactment of the Defense of Marriage Act (DOMA) in 1996, federal agencies and courts administering federal law consistently followed state definitions of marriage. ${ }^{24}$ The only issues of recognition have involved conflicts between the laws of different states.

DOMA, however, stated that in federal statutes or regulations, marriage and spouse were to be interpreted only to refer to different-sex unions. ${ }^{25}$ Accordingly, until Windsor was decided, the federal government denied recognition to same-sex marriages. And, crucially important, prior to Windsor, federal agencies interpreted DOMA as also precluding recognition of same-sex civil unions or domestic partnerships. This is apparent from the Social Security Administration's refusal to recognize such alternative statuses under the Social Security Act, even where application of the plain language of the authorizing statute would otherwise have required it. ${ }^{26}$

In other words, in the pre-Windsor world, the federal government treated same-sex domestic partnerships and civil unions as "marriages" functionally barred by DOMA. Accordingly, when Windsor was decided and the relevant provisions of DOMA were no longer enforceable, the agencies that administer the vast array of federal benefits, privileges, and obligations premised on marriage needed to determine whether they would recognize civil unions or domestic partnerships. This was an open question at the time - and, unfortunately, it has been answered incorrectly.

The federal agencies that have issued guidance responding to Windsor have been almost uniform in refusing to recognize civil unions or domestic partnerships as providing access to federal "marriage" benefits or obligations (with Social Security being a prominent exception, as discussed below). The Office of Personnel Management (OPM) was among the first agencies to issue such guidance, and it was one of the few to provide any kind of explanation for refusing to recognize domestic partnerships or civil unions. According to OPM's initial guidance on employee benefits, this exclusion was justified because "[t]he Supreme Court's decision addressed the constitutionality of a statute that defined 'marriage' and 'spouse' for

23. See Deborah A. Widiss, Leveling Up After DOMA, 89 Ind. L.J. 43, 46-50 (2014).

24. In a few discrete contexts, most prominently immigration, the federal government requires evidence of a valid state marriage and additional factors demonstrating "real" commitment. See Kerry Abrams, Marriage Fraud, 100 Calif. L. Rev. 1, 30-37 (2012).

25. 1 U.S.C. $\S 7$ (2012).

26. See infra note 36 and accompanying text. 
purposes of federal law to include only opposite-sex couples." 27 This sentence, of course, logically entails nothing about the recognition or nonrecognition of civil unions, so it is no explanation at all.

Later, when issuing new regulations for the federal employee health benefits program, OPM stated, in response to comments that had suggested providing benefits to same-sex domestic partners, it could not do so because the relevant federal statute "defines 'member of [employee's] family' to mean the employee's 'spouse' and certain children. Same-sex domestic partners are not encompassed within the statutory definition of member of family." 28 Here it becomes clear that the Name Claim is doing the work. It is because - and only because - those domestic partners are not called "spouses" that they cannot be recognized for federal purposes. By this reasoning, civil unions or domestic partners should be recognized if the state statutes provided that members of them were labeled "spouses." (This argument is especially perverse as applied to state laws, like New Jersey's, that actually do provide that members of civil unions are encompassed within statutory references to "spouse." ${ }^{29}$ )

Most agencies other than OPM have denied recognition to civil unions or domestic partnerships without any discussion of the rationale for doing so. For example, the IRS issued a lengthy opinion letter explaining why it was adopting a place of celebration approach for determining which marriages are valid, and how it would interpret "husband" and "wife" as gender neutral where necessary to avoid potential constitutional problems, but then simply making a conclusory statement, without any analysis, that the terms would not be interpreted to encompass registered

27. U.S. Office of Pers. Mgmt., Benefits Admin. Letter No. 13-203, Coverage of SameSEX SpOuSES at 1-2 (2013), http://www.opm.gov/retirement-services/publications-forms/ benefits-administration-letters/2013/13-203.pdf; see also U.S. OfFICE OF Gov'т Етнісs, LA13-10, Effect of the Supreme Court's Decision in United States $v$. Windsor on the Executive Branch Ethics Program 2 (2013) http://www.oge.gov/OGE-Advisories/Legal-Advisories/ Assets-non-searchable/LA-13-10--Effect-of-the-Supreme-Court-s-Decision-in-United-Statesv--Windsor-on-the-Executive-Branch-Ethics-Program-(PDF)/ (providing the same explanation regarding government ethics rules, although suggesting that a domestic partner might be recognized as a member of a household or a relative); U.S. Office of Pers. Mgmt., Tribal Benefits Admin. Letter No. 13-601, Coverage of Same-Sex Spouses 1 (2013), http://www. opm.gov/healthcare-insurance/tribal-employers/hr-personnel/bals/13-601.pdf (providing the same explanation regarding access to tribal employee benefits).

28. Final Rule Amending Federal Employees Health Benefits Program, 78 Fed. Reg. $64,873,64,875$ (Oct. 30, 2013) (citing 5 U.S.C. § 8901(5) (2012)). In this amendment to the regulations, OPM did make clear that a child of a federal employee's domestic partner could, in certain circumstances, be eligible for coverage as a step-child. See id. at 64,877 (to be codified at 5 C.F.R. $\S 890.302(2)(b))$. OPM offered the same explanation regarding a statutory reference to "spouses" as the justification for denying FMLA leave rights to domestic partners. Frequently Asked Questions: Same Sex Domestic Partner Benefits, U.S. Office PersonNEL MGMT., http://www.opm.gov/faqs/topic/domesticpartner/?page=2 (Feb. 13, 2015).

29. E.g., N.J. Stat. AnN. § 37:1-33 (West 2002 \& Supp. 2014). 
domestic partnerships or civil unions. ${ }^{30}$ (This ruling causes practical difficulties for couples who are accordingly treated as married for state purposes but unmarried for federal purposes, a particular challenge in community property states such as Nevada or California. ${ }^{31}$ ) Likewise, again without discussion or explanation, the Department of Labor stated that it will not require pension plan administrators to recognize civil unions or domestic partnerships. ${ }^{32}$ The State Department does not consider a civil union or domestic partnership sufficient to sponsor a partner for immigration purposes. ${ }^{33}$ Civil unions and domestic partnerships are generally not recognized for Medicare or Medicaid purposes, ${ }^{34}$ and income of a partner in a civil union or domestic partnership will not be considered when determining an individual's eligibility for financial aid. ${ }^{35}$

There are a few agencies that provide some discrete benefits to couples in civil unions or domestic partnerships. Most significantly, in June 2014, the Social Security Administration (SSA) announced that it would recognize civil unions or domestic partnerships that provide inheritance rights, following provisions in the Social Security Act that state explicitly that individuals may claim benefits based on relationships that are not "marriages" under a claimant's home state's law but that provide a right to inherit intestate. ${ }^{36}$ This is a welcomed policy development. However, the rationale on which the SSA made the determination is circumscribed in its applicability; it is premised on accepting the assertion that these relationships are not "marriages" but are covered by particular statutory language related to

30. See Rev. Rul. 2013-17, 2013-38 I.R.B. 201; see also Answers to Frequently Asked Questions for Registered Domestic Partners and Individuals in Civil Unions, IRS, http:// www.irs.gov/uac/Answers-to-Frequently-Asked-Questions-for-Registered-Domestic-Partnersand-Individuals-in-Civil-Unions (last updated Aug. 19, 2014).

31. See Answers to Frequently Asked Questions for Registered Domestic Partners and Individuals in Civil Unions, supra note 30 (discussing how to handle such dual filings).

32. Emp. Benefits Sec. Admin., U.S. Dep't of Labor, Technical Release No. 2013-04, Guidance to Employee Benefit Plans on the Definition of "Spouse" and "Marriage" Under ERISA and the Supreme CourT's Decision in UNITED STATES V. WindSOR (2013), http://www. dol.gov/ebsa/pdf/tr13-04.pdf.

33. U.S. Visas for Same-Sex Spouses: FAQs for Post-Defense of Marriage Act, U.S. Dep'T ST., http://travel.state.gov/content/dam/visas/DOMA/DOMA\%20FAQs.pdf (Mar. 21, 2015).

34. Ctrs. for Medicare \& Medicaid Servs., U.S. Dep't of Health \& Human Servs., SHO No. 13-006, Re: UNITED STATES V. WINDSOR (2013), http://www.medicaid.gov/Federal-PolicyGuidance/downloads/SHO-13-006.pdf. Civil unions and domestic partnerships may occasionally be recognized if states administering the programs recognize such statuses as marriages. Id. at 1-2; see also infra text accompanying note 41.

35. U.S. Dep't of Educ., GEN-13-25, Supreme Court Ruling on the Defense of Marriage Act and the Implications for the Title IV Student Financial Assistance Programs (2013), http://www.ifap.ed.gov/dpcletters/attachments/GEN1325.pdf.

36. See Public Health and Welfare Act, 42 U.S.C. § 416(h)(1)(A)(ii) (2012); see also U.S. Soc. Sec. Admin., GN 00210.004, Non-Marital Legal Relationships (Such as Civil Unions and Domestic Partnerships) (2014), available at https://policy.ssa.gov/poms.nsf/ $\operatorname{lnx} / 0200210004$. 
inheritance rights, rather than properly recognizing that these relationships are functional marriages and should be treated as such. (Because the statute also prescribes a domicile approach to determining which marriages are recognized, the SSA, unlike any other federal agency, accords "marital" rights to civil unions or domestic partnerships, but it is not yet clear whether it will provide benefits to couples with out-of-state marriages that are not recognized in a same-sex couple's home state. ${ }^{37}$ )

Additionally, prior to Windsor, both the U.S. Department of Defense and the Department of Veterans Affairs were considering proposals to recognize such alternative statuses for certain limited purposes. In guidance issued since Windsor, these agencies have suggested they will move forward on these plans, ${ }^{38}$ although the Department of Defense abandoned a more ambitious plan to establish its own domestic partnership status that would have provided the full range of "spousal" benefits to partners of military employees. ${ }^{39}$ OPM makes limited employment benefits available to same-sex partners of federal civilian employees under provisions that reference "family members," or pursuant to executive orders that encourage or require agencies to grant specific benefits to domestic partners. ${ }^{40}$ And the Department of Health and Human Services has suggested that, because Medicaid and the Children's Health Insurance Program are administered as federal-state partnerships, a state may choose to recognize civil unions or domestic partnerships for these programs if it "recognizes ... [such statuses] as a marriage." 41

Despite these rare exceptions, the relative uniformity of the denial of federal benefits has bolstered arguments that civil unions or domestic partnerships are an inadequate substitute for marriage. Prior to Windsor, such claims focused on necessarily abstract discussions of the symbolic importance of the word "marriage"

37. See 42 U.S.C. $\$ 416(\mathrm{~h})(1)(A)(\mathrm{i})$; see also Robin Maril \& Carroll Estes, Hum. Rts. Campaign \& Nat'l Comm. to Preserve Soc. Sec. \& Medicare, Living Outside the Safety Net: LGBT Families \& Social Security (2014), http://www.ncpssmfoundation.org/Portals/0/ lgbt-report.pdf.

38. See Declaration/Dissolution of a Same-Sex Domestic Partnership for DEERS Enrollment, 78 Fed. Reg. 54,634 (Sept. 5, 2013); Vet Center Services, 78 Fed. Reg. 57,067, 57,06769 (Sept. 17, 2013) (to be codified at 38 C.F.R. pt. 17) (allowing domestic partners access to services, but only for certain kinds of counseling).

39. See Memorandum from Chuck Hagel, Sec'y of Def., to Sec'ys of the Military Dep'ts Under Sec'y of Def. for Pers. \& Readiness, Extending Benefits to the Same-Sex Spouses of Military Members (Aug. 13, 2013), http://www.defense.gov/home/features/2013/docs/ Extending-Benefits-to-Same-Sex-Spouses-of-Military-Members.pdf (stating that "the extension of benefits to the same-sex domestic partners of military members is no longer necessary to remedy the inequity that was caused by section 3 of the Defense of Marriage Act").

40. See generally Feddesk, Federal Guide: 2013 Domestic Partner Guide (2013), http:// feddesk.com/freehandbooks/042613-1.PDF (reviewing the extent to which domestic partners could qualify for benefits prior to the Windsor decision in 2013). It is possible that some agencies may scale back access to such domestic partner benefits for employees in states where they can now marry a same-sex partner.

41. Ctrs. for Medicare \& Medicaid Servs., supra note 34, at 4-5. 
or the insult implied in establishing a separate status for (at least primarily) gay and lesbian couples. But now the injury is obvious and tangible. This argument was successful in New Jersey ${ }^{42}$ and Oregon, ${ }^{43}$ and in cases in Illinois that granted terminally ill members of civil unions the right to marry before that right was generally available. ${ }^{44}$ In these cases, the state defendants have generally argued that the federal government should simply recognize such alternative statuses as marriages. The New Jersey court, at least, considered this a plausible alternative approach but was unwilling to shift responsibility away from the states themselves. ${ }^{45}$

\section{The Fallacy of the Name Claim}

The law of recognition of foreign marriages has been well settled for a long time. Ordinarily, a marriage valid where celebrated is valid everywhere. ${ }^{46}$ Since the founding of the country, the federal government has routinely recognized marriages celebrated in foreign countries. ${ }^{47}$ After Windsor, Secretary of State John Kerry announced that the same rule would be applied to foreign same-sex marriages: "As long as a marriage has been performed in a jurisdiction that recognizes it so that it is legal, then that marriage is valid under U.S. immigration laws, and every married couple will be treated exactly the same . ..." ${ }^{48}$

Recall the Name Claim: a union must be designated by the word "marriage," in the jurisdiction that recognizes it, in order to be treated as a marriage in federal law.

The Name Claim is inconsistent with more than two centuries of federal practice. Most of the world's population does not speak English and so does not use the word "marriage." In German, the word is "Ehe." In Spanish, it is "matrimonio."

42. Garden State Equal. v. Dow, 82 A.3d 336, 367-68 (N.J. Super. Ct. Law Div. 2013).

43. Geiger v. Kitzhaber, 994 F. Supp. 2d 1128, 1143-44 (D. Or. 2014).

44. Lee v. Orr, No. 13-cv-8719, 2013 WL 6490577, at *3 (N.D. Ill. Dec. 10, 2013); Gray v. Orr, 4 F. Supp. 3d 984, 992-94 (N.D. Ill. 2013).

45. See, e.g., Garden State Equal., 82 A.3d at 365.

46. Peter Hay, Patrick J. Borchers \& Symeon C. Symeonides, Conflict of Laws 621-23

(5th ed. 2010); Restatement (Second) of Conflict of LaWs § 283(2) (1971); Restatement of Conflict of Laws $\S 121$ (1934); Joseph Story, Commentaries on the Conflict of Laws, Foreign and Domestic, in Regard to Contracts, Rights, and Remedies, and Especially in Regard to Marriages, Divorces, Wills, Successions, and Judgments 187-88 (Melville M. Bigelow ed., 8th ed., Boston, Little, Brown \& Co. 1883) (1834). For an overview of the relevant law, see Andrew Koppelman, Same Sex, Different States: When Same-Sex Marriages Cross State Lines (2006).

47. We have been unable to find a citation for this obvious fact. The practice is so routine that, so far as we can tell, it has never occurred to anyone to question it. For a discussion of current law, see Marriage Abroad, U.S. DEP'T ST., http://www.travel.state.gov/content/passports/english/abroad/events-and-records/marriage.html (Mar. 22, 2015).

48. Daniel Politi, Kerry: Same-Sex Married Couples Will Receive Equal Treatment During Visa Application Process, The Slatest (Aug. 2, 2013, 1:45 PM), http://www.slate.com/blogs/ the_slatest $/ 2013 / 08 / 02 / j \mathrm{john}$ _kerry_kerry_gay_married_couples_will_be_treated_equally_ for_u_s_visas.html. 
In Chinese, it is "Hūnyīn." And so forth. The same is true with respect to "spouse," on which the OPM's reasoning turns. German: "Gattin." Spanish: "cónyuge." Chinese: "Pèi'ǒu." Marriages originally denominated with these words have always been recognized in federal law. If the Name Claim truly controls federal policy, we could conclude that American practice has been wrong all these years. That, however, would be crazy. The other alternative is to say that the OPM and other federal agencies have not adequately analyzed the question before it.

As discussed in Part I, many states created civil unions or domestic partnerships that provide full marital rights to same-sex couples and impose full marital obligations on couples. The couples who enter such relationships thus make precisely the same commitment to each other that married couples make-in most instances, they commit to an open-ended, hopefully lifelong, partnership in which they will share their property and income and support each other in providing the necessities of life. ${ }^{49}$ Federal law incorporates by reference state marriage law, ${ }^{50}$ and state marriage law explicitly states that such alternative statuses are to be treated as marriages. ${ }^{51}$ Thus, regardless of the name attached to the status, the relationship should be recognized, triggering marital rights, benefits, and responsibilities under federal law, just as foreign marriages trigger marital rights, benefits, and responsibilities under federal law.

Put differently, the civil union and domestic partnership statutes aim to separate out social meaning from administrative consequences and to create a functional equivalent of marriage with all the same administrative consequences. Federal recognition is an administrative consequence of state marriage and thus federal recognition should flow from the entrance into a marriage-equivalent status. Indeed, the state and federal systems are intended to work together. For example, an

49. Of course, both same-sex and different-sex couples may depart from statutory defaults through prenuptial or postnuptial agreements.

50. As noted above, there is variation between federal laws that look to only the state law where the couple is domiciled, see, e.g., Public Health and Welfare Act, 42 U.S.C. $§ 416(\mathrm{~h})$ (1)(A)(i) (2012) (explaining Social Security will recognize a marriage if the courts of the state where the couple was domiciled would recognize the marriage), and federal laws that will recognize any valid state marriage, even if the couple's domicile state does not recognize it, Emp. Benefits Sec. Admin., supra note 32 (explaining that in interpreting ERISA, "the term 'spouse' will be read to refer to any individuals who are lawfully married under any state law"). But the more general proposition - that federal law looks to state law to determine valid marriages - is generally consistent across the federal code, other than in a few discrete contexts, such as immigration, where federal law may require showing of a valid state marriage and additional factors. See generally Abrams, supra note 24.

51. See supra text accompanying notes 16-19. 
individual or couple's personal state income tax filings are built on the foundation of an individual or couple's federal income tax filing. ${ }^{52}$

A potential objection to our argument-which may be what the OPM and other federal agencies have in mind, although if so it is barely articulatedis that the social meaning, and so perhaps the felt significance and durability, of marriage is so different from that of civil unions or domestic partnerships that it is appropriate for the federal government to treat the two differently. ${ }^{53}$ Once again, however, Congress has made no such judgment. The federal law rests on state law and should follow the state legislative judgment that these statuses are to operate as functional marriages.

Our claim that the federal government should recognize civil unions and domestic partnerships is limited simply to alternative statuses that include full state marital rights and obligations. In states that have created alternative statuses that provide only partial state marital rights, the federal government could reasonably distinguish between such unions-formed by either same-sex or different-sex couples - and marriages or alternative statuses that are fully equivalent to marriages. Thus, for example, the federal government should recognize couples who have formed civil unions in Colorado because they have committed to a relationship that provides all of the "rights, benefits, protections, duties, obligations, responsibilities, and other incidents under law as are granted to or imposed upon spouses." 54 The federal government could, however, reasonably decide that it would not grant federal "marital" rights to (same-sex or different-sex) couples who register as "designated beneficiaries" under a different provision of Colorado law that permits individuals to commit to some, but not all, marital rights. ${ }^{55}$ This is the same kind of distinction that the federal government currently makes between French marriages and the more limited "pacte civil" that is popular in France. ${ }^{56}$ That said, as one of us has argued elsewhere, the federal government should reconsider more generally the extent to which it relies solely on marriage — or marriage-equivalent-relationships to provide access to core federal rights and responsibilities supporting families. ${ }^{57}$

52. See, e.g., Ind. Dep't of Revenue, Indiana IT-40 Full-Year Resident Individual Income TAX BOOKLET 9 (2013) (explaining that individuals "must complete [their] federal income tax return before starting [their] Indiana income tax return [because] [1]ine numbers from [the] federal income tax return are referenced in many of the [Indiana] instructions"); see also Answers to Frequently Asked Questions for Registered Domestic Partners and Individuals in Civil Unions, supra note 30 (discussing how to handle dual filings required by the federal refusal to recognize civil unions or domestic partnerships that trigger state marital rights).

53. Our thanks to Tobias Wolff for helping us articulate this point.

54. Colo. Rev. Stat. Ann. § 14-15-107(1) (West 2005 \& Supp. 2014).

55. See Colo. Rev. Stat. Ann. §§ 15-22-101 to 15-22-106 (West 2011 \& Supp. 2014).

56. U.S. Embassy, Marriage and PACS (Civil Partnerships) in France (2014), http://photos.state.gov/libraries/france/45994/acs/usc_paris-marriage.pdf.

57. See Widiss, supra note 23 , at $62-65 \& \mathrm{nn} .88-104$, for a discussion of the advantages of unbundling marital privileges under federal law. 
Some benefits that are currently limited to married couples should be made available to a broader array of relationships; others might be effectively tailored more narrowly. ${ }^{58}$

We contend automatic federal recognition of alternative statuses is appropriate regardless of why a couple may have chosen to enter into the alternative status - so long as the status was in fact the legal equivalent of marriage. As noted above, there are three primary categories here: (1) couples who formed civil unions or domestic partnerships as a second-best option because marriage was not permitted; (2) couples who formed civil unions or domestic partnerships as a mechanism for expressing their commitment while also registering opposition to or discomfort with the institution of marriage; and (3) couples who formed civil unions or domestic partnerships to take advantage of being "married" for state purposes and "unmarried" for federal purposes.

Application of our argument to couples in the first category-those who would have preferred to marry if they could have-is easy. (Our intuition is that this is probably the largest category by far; however, we do not know of data that establishes this definitively.) There are undoubtedly some such couples where one partner no longer has the capacity to consent to a formal legal relationship. ${ }^{59}$ For these couples, the new availability of legal marriage provides no recourse, but the federal government has the authority to ensure that they are not currently harmed by the lingering effects of prior discrimination. Like the federal government's embrace of place-of-celebration rules, this offers a mechanism for the federal government to help remedy the injury caused by state discrimination against same-sex couples.

Even couples in this first category who have since married may be injured by the federal government's refusal to recognize that they made "marital" commitments to each other within such alternative statuses. For example, after Windsor was decided, the Internal Revenue Service permitted same-sex couples who were married to amend earlier tax returns so they could claim refunds where they would have owed less money if their marriages had been recognized. ${ }^{60}$ Couples

\footnotetext{
58. See id.

59. For a discussion of same-sex couples in California who formed domestic partnerships but cannot or choose not to marry, see Responsive Brief of Plaintiff Class Re Subsequent Legal Developments at 7-8, Dragovich v. U.S. Dep't of Treasury, No. CV 4:10-01564-CW, 2014 WL 6844926 (N.D. Cal. Dec. 4, 2014). The plaintiffs in Dragovich had claimed that the refusal to recognize California domestic partnerships as "marriages" under federal law, which in turn meant that they were also not recognized under a California benefit plan, violated the Equal Protection and Due Process clauses. The court ultimately denied the Plaintiff's class's request for further discovery to identify specific couples who faced barriers to marriage, deeming the issue too individualized for class relief, and, in the absence of evidence of such harms, granted summary judgment to the government on these claims. See Dragovich v. U.S. Dep’t of Treasury, No. CV 4:10-01564-CW, 2014 WL 6844926, at *5-6 (N.D. Cal. Dec. 4, 2014).

60. Rev. Rul. 2013-17, 2013-38 I.R.B. 201.
} 
who were in civil unions or domestic partnerships that were equivalent to marriage were not offered this opportunity. Similarly, eligibility for benefits under the Social Security Act can turn on the duration of a formal legal relationship prior to a claim being filed. The SSA has indicated that it will consider the length of marriages that pre-dated Windsor (and also, since it is recognizing domestic partnerships and civil unions, the length of these relationships that pre-dated Windsor), but it has not established whether it will "combine" such statuses when making determinations. ${ }^{61}$ A couple in a civil union or domestic partnership who later marries risks resetting the clock - and for some couples, this could happen at just the wrong time. Similar issues can arise for spouses claiming benefits after the death of a federal employee, and at least one administrative law judge has properly reasoned that a California domestic partnership should be combined with a subsequent marriage when determining whether a statutory durational requirement had been met to avoid constitutional issues that would otherwise arise. ${ }^{62}$

We believe that federal recognition should also be automatic for couples in the third category - the instrumentalists. Federal law makes choices regarding the lines drawn among and between families. While one might disagree with some of the policies embedded in those categories, permitting a small number of couples to opt out of selective parts of the package distorts the larger policy choices. For example, the current federal policy of non-recognition permits couples who make relatively equal salaries to lessen their federal tax burden while enjoying the benefits of a functional marriage under state law. In states where alternative statuses are only available to same-sex couples, this disadvantages comparable different-sex couples, a strange inversion of the pre-Windsor inequalities. Even if both same-sex and different-sex couples are able to enter into an alternative status in a particular state, the existing federal policy causes interstate variation that likewise undermines federal policy objectives. Indeed, a primary argument in favor of the joint federal return in the first place was to address the fact that individual returns by married couples advantaged couples in states that had adopted community property regimes. ${ }^{63}$

For related reasons, we believe that automatic federal recognition of state marriage equivalents is also appropriate in jurisdictions - such as in Californiawhere state legislators have made an alternative status that provides full marital rights only available to different-sex couples who were retirement-aged ${ }^{64}$ Again, the

61. See U.S. Soc. Sec. Admin., supra note 36, ex.3.

62. See Kapple v. Office of Personnel Mgmt., No. SF-0843-15-0082-I-1, 2015 WL 241655

(M.S.P.B. Jan. 16, 2015) (interpreting "marriage" in federal statute to include domestic partnership and noting that doing so furthered the underlying purpose of the statutory language as identifying couples who had made a "serious, long-term commitment to one another"); see also In re Fonberg, 736 F.3d 901 (9th Cir. Jud. Council 2013) (holding failure to enroll the domestic partner of a federal employee under a family health plan was discrimination on the basis of sex and sexual orientation).

63. See Widiss, supra note 23, at 48-49.

64. See Cal. Fam. Code $\S 297(b)(5)(B)$ (West $2004 \&$ Supp. 2015). 
federal Social Security system, and other federal policies, makes choices regarding what actions will trigger the cessation of benefits. Again, one might disagree with these choices, but it is problematic to offer a strategic opt-out to couples in only a few select states. States may, as New Jersey has, create alternative statuses that provide a discrete subset of marital rights, such as the right to make health care decisions for a partner or the right to inherit property tax free, available to senior citizens (or individuals more generally) who are not married ${ }^{65}$ If such alternative statuses are not fully the equivalent of state marriage, they would not, under our analysis, automatically trigger federal recognition; that said, federal agencies and private actors could of course consider changing specific policies to encompass such statuses.

And finally, we believe that our argument applies to couples in the second category - the marriage "resisters." Such couples have, despite their opposition to the institution of marriage, entered into a formal legal relationship that functions like a marriage. Presumably they therefore seek the administrative benefits that flow from such a relationship, and many might welcome federal recognition. Moreover, recognition through the indirect process of a federal statute incorporating a state definition of what "counts" as marriage would indicate no more support for the institution of marriage than their initial willingness to form the civil union or domestic partnership did. But whether or not such couples would choose federal recognition, we cannot imagine a practical mechanism that would effectively sort between couples who would opt out of federal recognition for sincere ideological reasons and couples who would opt out of federal recognition for the kind of instrumental reasons we have deemed inappropriate.

Couples in any of these categories who would like to avoid federal recognition can of course dissolve their civil union or domestic partnership. And states can continue to experiment with alternative statuses that provide a more limited bundle of rights and responsibilities than marriages. But if a relationship entails full marital rights, benefits, and responsibilities under state law, it should likewise trigger marital rights and responsibilities under federal law-whatever name is attached to the status.

\section{CONCLUSION}

What is remarkable about the OPM's and other federal agencies' refusal to recognize civil unions and domestic partnerships is that it reproduces one of the central flaws of DOMA. DOMA denied recognition to thousands of marriages that

65. See N.J. Dep't of Health, Reg-D33, Registering a Domestic Partnership in New JerSEY (2012), http://www.state.nj.us/health/forms/reg-d33.pdf (explaining that limited domestic partnerships are available to same-sex or different-sex couples where a member of the couple is over sixty-two, whereas civil unions providing full marital rights are only available to same-sex couples). 
were unquestionably valid under state law. In so doing, it thwarted the purposes of every federal law that recognized existing marriages. Those marriages were created by states in order to give administrative recognition to family relationships on which people depend.

DOMA deemed the interest in nonrecognition of same-sex couples to be so overridingly urgent as to justify sacrificing a huge range of other government interests, some of the highest order. ${ }^{66}$ Bankruptcy courts could not accomplish efficient and predictable adjudication. Government employees could not insure their dependents. The Social Security survivor benefits program could not accomplish its goal of meeting the needs of dependents and beneficiaries. Retirees could not provide for the security of their dependent spouses. Income taxation could not take account of family obligations. National safety itself was compromised because the military could not provide its members' families with healthcare, housing, and survivorship benefits that are essential to military effectiveness. ${ }^{67}$

The current federal policy perpetuates these pathologies by continuing to treat some couples as "married" for state purposes and "unmarried" for federal purposes. The ongoing harms that this policy imposes - on same-sex couples and on society as a whole - are unnecessary. Federal law, properly interpreted, permits recognition of state statuses that functionally are marriages. And furthermore, the U.S. Constitution may require recognition. That is, if it was unconstitutionally irrational for the government, through DOMA, to accept these costs in order to make a stand in opposition to same-sex marriage, then it seems likely that it is also unconstitutionally irrational for the government to continue to do so, not even for the sake of a gesture, but solely on the basis of a semantic confusion.

66. This manifest devaluation of gay people was apparent on the face of the statute and did not depend on a showing of subjective intent to harm. See Andrew Koppelman, Beyond Levels of Scrutiny: Windsor and "Bare Desire to Harm", 64 CaSe W. Res. L. Rev. 1045 (2014); Andrew Koppelman, Romer v. Evans and Invidious Intent, 6 WM. \& Mary BiLl RTs. J. 89, 96-137 (1997). We are not attributing any such subjective intent to the OPM or other federal agencies.

67. See Koppelman, Beyond Levels of Scrutiny: Windsor and "Bare Desire to Harm", supra note 66 , at $1063-65$, for a documentation of these pathologies. 